\title{
Word of Mouth to Word of Mouse: A Study
}

Effulgence

Vol. 16 No. 1

January - June, 2018

Rukmini Devi Institute of Advanced Studies

E-mail : effulgence@rdias.ac.in, Website : www.rdias.ac.in

http:/ / effulgence.rdias.ac.in/user/default.aspx

https://dx.doi.org/10.33601/effulgence.rdias/v16/i1/2018/51-60

\section{Rutika Saini ${ }^{1}$ \\ Dr. H K Dangi ${ }^{2}$}

\begin{abstract}
Electronic marketing has been used by various marketers to reach the target audience. With the passage of time online social networks and company websites are increasingly being adopted as a source of disseminating information. Viral marketing is a promotional strategy that uses social networks to influence consumers and make them purchase a particular product. Traditionally, the marketer used to advertise their product to each potential customer. The rise of internet has made it easier to reach customer. Now they are inducing their customers to pass on the message. This study compares traditional strategies with viral marketing strategy. The paper examines previous researches and synthesise them. Literature indicates that effectiveness of viral marketing campaign is still questionable. Despite the increasing trend of viral marketing there is an uncertainty about the effectiveness of campaign. The present study identify various factors that leads to the success of a viral marketing campaign.
\end{abstract}

Keywords: Viral Marketing, Buzz Marketing, Electronic word of mouth.

\section{INTRODUCTION}

$\mathrm{M}$ arketing Communication is no longer oneway (marketer to customers) approach. In contemporary world communication flows in multiple directions. Modern marketing communication explore the links that customers have with their peer groups through social media. Customers are resisting to outdated forms of promotion such as TV or newspaper ads. Recently marketers are moving towards innovative strategies, including viral marketing. Viral marketing is a strategy that encourages potential consumers to broadcast a message. Opinion of peers highly affects customers. Customers usually look for references while choosing a product or service. Customers tend to trust a personal recommendation given by a friend or trusted social contact. Viral marketing through social media is better and more powerful than third party advertising, as it conveys an indirect certification from social connections that can be either friends, celebrities or any trusted person. Viral marketing campaigns provide an efficient alternative for spreading advertising messages to consumers. It is a human tendency to be more interested in purchasing decisions of a known person than an anonymous person. Many companies use social

1. Assistant Professor, University of Delhi

2. Associate Professor, University of Delhi

Corresponding Author

Rutika Saini , Assistant Professor, University of Delhi 
media space to promote their product and services. Viral marketing has also proved to be an important tool to launch a new product and expose the brand in front of a large potential market quickly. A YouTube video is an inexpensive alternative to a TV commercial, but if people get inspired to share a message through videos then it can have a major impact on brand recognition. Viral marketing is an attractive promotion tool for small businesses because viral marketing is a cost effective alternative to traditional marketing efforts. A recent report by DOMO "Data never sleeps 5.0" recently revealed users watch 41, 46,600 videos every minute. One successful example of a viral marketing was a campaign by Burger king. In promotion campaign of its new Tendercrisp sandwich, a website was designed by Burger King that allowed users to give commands to the "Subscrvient Chicken" a man in a chicken costume. It was observed that people used to leave websites within eight seconds of visiting, many of Burger King's 15 million first-week visitors to the subservient chicken page spent six minutes or more.

The introduction of social networks such as, online communities, videos and emails, blogs, and forums provide the facility to allocate information faster than ever before. Viral marketing can spread message to millions of people in a short time in an effective manner. These advancements in technology and marketing communication are opening up enormous opportunities for businesses to appeal larger markets. Viral Marketing is not easy or straightforward. On the basis of past experience it has been observed that all such marketing campaigns have not been always successful. There is always an uncertainty about effectiveness of Viral Marketing campaigns. Prediction of customer's reaction or response to online marketing messages is not easy. A famous example of failed viral marketing campaign is Chipotle's twitter 'hack'.Chipotle in its anniversary campaign, decided to incorporate social media and came up with the idea of orchestrating a pretend Twitter 'hack'.

In its viral marketing campaign Chipotle sent out a series of random tweets and later apologized for the same saying that their Twitter account had been hacked. But actually it was a deliberate move by the company and it was the part of campaign. Tweets contained clues about the ingredients the chain uses to make its guacamole. Although their campaign attracted and engaged more followers, Chipotle's followers criticised the campaign because they had been duped and the brand received complaints about the stunt.

Viral marketing is an emerging trend and has huge potential. However viral marketing is a delicate strategy and an extra care has to be taken while executing the campaign. The paper focus on evolution of viral marketing and how it is different from traditional marketing on the basis of previous researches. The paper is organized as follows: In Section 2, we provide a literature review related to research in viral marketing. Section 3 offers the details of the methodology used in this paper. In Section 4, we present and discuss results. Finally, we conclude and suggest direction for future research in Section 5.

\section{REVIEW OF LITERATURE}

Douglas Rushkoff, is being credited for the popularity of term viral marketing through his book, Media Virus in 1994. The term viral marketing was suggested by Jeffrey Rayport, a faculty member at Harvard Business School, in his article "The Virus of Marketing" (1996). The term further popularized by Draper and Jurvetson in 1997. They defined the term as "network-enhanced word-of-mouth. Viral marketing is an approach in which individuals are inspired to pass on a marketing message to others. Such strategies advantageously use social media to explode the message to thousands, indeed millions.

Literature related to viral marketing is at nascent stage. The term has been defined differently by different researchers. Following table summarizes common definition of viral marketing frequently mentioned in literature. 
Table 1: Viral marketing defined by various authors

\begin{tabular}{|c|c|}
\hline Author (year) & Definition \\
\hline J.Chevalier (2004) & $\begin{array}{l}\text { Viral marketing, known also as word-of-mouth marketing, refers to a } \\
\text { marketing mode attached to some carriers on the Internet, which can } \\
\text { rapidly copy marketing information at a low cost. }\end{array}$ \\
\hline $\begin{array}{l}\text { Liu-Thompkins, } \\
\text { (2012) }\end{array}$ & $\begin{array}{l}\text { Viral marketing defined as "the act of propagating marketing messages } \\
\text { through the help and cooperation from individual consumers" }\end{array}$ \\
\hline $\begin{array}{l}\text { Kiss and Bichler } \\
(2008)\end{array}$ & $\begin{array}{l}\text { Marketing techniques that use social networks to produce increases in brand } \\
\text { awareness through self-replicating viral diffusion of messages, analogous to } \\
\text { the spread of pathological and computer viruses. }\end{array}$ \\
\hline $\begin{array}{l}\text { Bryant \& Miron } \\
(2004)\end{array}$ & $\begin{array}{l}\text { Viral marketing is an advertising strategy that takes the advantage of the } \\
\text { effect of "word of-mouth" among the relationships of individuals to } \\
\text { promote a product. Instead of broadcasting to a massive number of users } \\
\text { directly as existing advertising methods }\end{array}$ \\
\hline Aga & $\begin{array}{l}\text { Viral marketing is a marketing mode taking advantage of some medium } \\
\text { carriers, which can rapidly self-replicate marketing messages or "buzz" at a } \\
\text { low cost through word of mouth among a large number of individuals. It is } \\
\text { essentially an issue concerning the spread of messages over the so-called } \\
\text { "digitally enabled social networks". }\end{array}$ \\
\hline Bamp & $\begin{array}{l}\text { Viral marketing broadly describes any strategy that encourages individuals } \\
\text { to propagate a message, thus creating the potential for exponential growth } \\
\text { in the message's exposure and influence }\end{array}$ \\
\hline $\begin{array}{l}\text { Kaikati and Kaikati } \\
(2004)\end{array}$ & $\begin{array}{l}\text { It refers to word of mouth via a digital platform... spreading the message } \\
\text { via 'word of mouse' and ensuring that the receivers have the interest to pass } \\
\text { along the message to their acquaintances }\end{array}$ \\
\hline Dobe & $\begin{array}{l}\text { Strategy encouraging individuals to pass on messages received in a } \\
\text { hypermedia environment, such as e-mail or other messaging system. }\end{array}$ \\
\hline $\begin{array}{l}\text { Van der Lans et al. } \\
(2005)\end{array}$ & $\begin{array}{l}\text { The term "viral marketing" describes the phenomenon by which consumers } \\
\text { mutually share and spread marketing-relevant information,initially sent } \\
\text { out deliberately by marketers to stimulate and capitalize on word of mouth } \\
\text { (WOM) behaviours. }\end{array}$ \\
\hline
\end{tabular}

As evident from above table the term wor of mouth is very close to viral marketing. There are variety of terminology that has been formally defined in the literature. According to Vilpponen et al. (2006), some of the terminology used to describe electronic word of mouth includes "Internet word-of-mouth" and "word-of-mouse" (Goldenberg et al., 2001), "stealth marketing" (Kaikati and Kaikati, 2004) and "referral marketing" (Bruyn and Lilien, 2004), "Interactive Marketing" (Blattberg and Deighton, 1991).Thomas (2004) tries to unify these ideas in the term "buzz marketing". Some researchers, including Welker (2002), draw an analogy between viral marketing and a living biological virus. Knight (1999) suggests that viral marketing is a similar to a "digitalised sneeze", one characterised by the release of "millions of tiny particles that can infect others who come into contact with them". Welker (2002) stresses the contagious power of a virus and suggests that a "virus replicates (itself) with geometrically increasing power, doubling with each interaction".

Viral marketing has emerged as the electronic form of word of mouth and follows the principle of passing on information to another person (Danilo; Chris, 2008). Jurvetson and Draper (1997) pointed 
that viral marketing uses the recommendations by friends and has a snowball effect. Viral marketing is powerful than other means of advertising because it conveys a recommendation from a known person, therefore the mail should be customized so that it shows that it is referred by a friend.

In a viral marketing campaign, the marketers create an online marketing message and encourage customers to forward this message to members of their social network. The growth of web leads companies such as Facebook, Twitter and Google to enhance connectivity among its users (Ratchford, 2015). Web has become the primary advertising channel for many companies through which they try to reach potential customers (e.g. via banner ads or social media ad campaigns), at the cost of bombarding them with often irrelevant information.

Viral marketing is an influence maximization problem which deals with selection of a set of seed users in a social network who spread the information and will fetch the largest possible number of starts among remaining users (Kempe et al. 2003).The cost to initiate the spread of information depends upon the number of seed users i.e. the larger the seed set size, the higher the cost. Viral marketing is viewed as a cost-effective marketing approach that drives sales in a short time and facilitates inter-connections among companies and potential buyers (Dobele et al., 2007). Viral marketing is a very effective internet marketing communication tool (Datta et al., 2005) and will succeed if companies understand their online customers and providing a better solution than those of competitors.

Marketers are being allowed to customize their strategies by social marketing technologies. These advancements also allow them to extend a dialogue with customers. Moreover, the online communication system helps marketers to better target their potential customers. Some sites which drive databases such as Facebook, segment population on the basis of demographics and interests (Gillan, 2009). However, the success of the media is determined by various other resources which are allocated to their proper use and evaluation. Word-of-mouth communications has become a hot topic for both practioners and researchers. Since the early 1950s, researches have shown that personal discussions and informal exchange of information among contacts not only influence decision of consumer, but also form consumer beliefs.

Some researches shows that electronic form of word of mouth have greater influence than other forms of traditional marketing such as print ads, personal selling, and radio advertising. Just like word of mouth, word of mouse can be proved as highly credible tool, but this credibility is offset by a lack of control over the message.

Helm (2000) suggested that the marketer's main goal behind viral marketing is to maximize reach. She stated that this principle is important to achieve competitive advantage through a viral message; however, it does not have any evidence to support this claim. In contrast, Juvertson (2000) stated that effectiveness can be measured on the basis of three criteria i.e. penetration, loyalty and frequency.

Brown and Reingen (1987) conducted a research on families of students who were getting classes from three piano teachers. They found that individuals get influenced by the people with whom they have strong ties in comparison to those with whom they have weak ties. Many studies have been performed in the same area. De Bruyn and Lilien observed that level of bonding and social tie influence people but influential power can vary with the difference in stage of decision making process. It is also observed that strength of tie aids awareness while demographic similarity does not have a positive influence on each stage of decision making.

Geographic similarity, age, similar interests are the factors which help in forming an interactive social network. It is also found that there are more chances of adoption of a new brand when a potential 
customer already has an interaction existing customer. Bowman and Narayan das (2001) stated that dissatisfied customers are more likely to talk about the product in comparison to satisfied customers.

Researches related to viral marketing is fragmented and scant. The paper aims to synthesis researches related to viral marketing is organized form. Researchers intends to present previous researches in a manner that can be useful for future researches.

\section{METHODOLOGY}

The research design for this paper is exploratory in nature. The dynamic nature of the topic entailed an exploratory investigation, through synthesized data collection from secondary sources. An extensive analysis of the existing literature on viral marketing campaigns has been carried out. Observations were made by reviewing the present literature on the theme of viral marketing using different data sources such as Google Scholar, Emerald, SAGE and EBSCO from 1999 onwards to 2017.Various related key words such as viral marketing, buzz marketing, electronic word of mouth and combinations of these were used to locate the relevant studies for analysis. Automated insights from an open software " $R$ " has been used for preliminary analysis of literature.

\section{FINDINGS AND DISCUSSION}

In order to investigate uses of term viral marketing, in total sixty five research papers on viral marketing were screened and analysed with the help of word frequency query in an open source software " $R$ " looking for 100 most frequently used words and their synonyms. The results are presented below in the form of a word cloud.

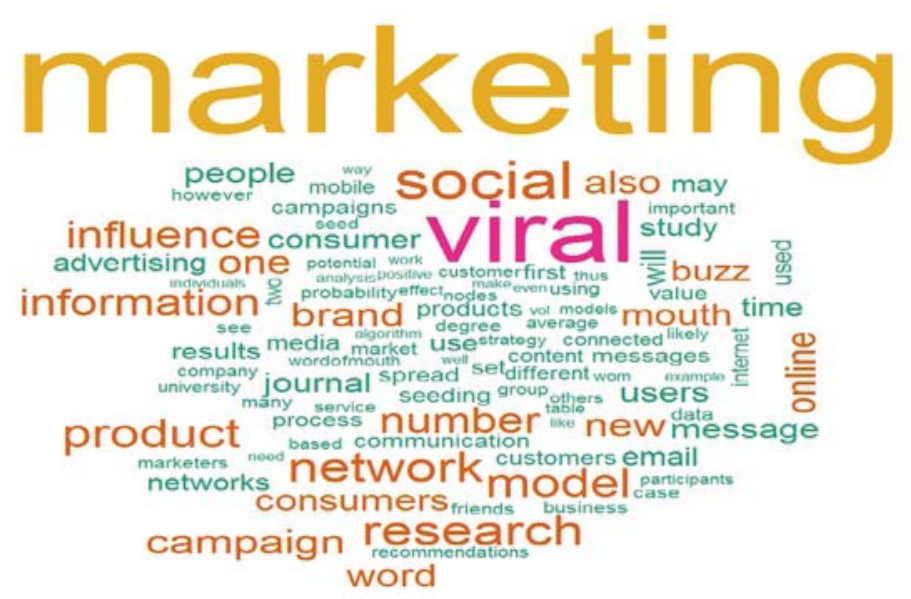

Figure 1: Word cloud of most frequently used words

According to results of word frequency query, the top three words used in literature are Marketing (5492 times), Viral (3056) times and Social (1804 times) which indicates that literature has been reviewed in the right direction and there has been considerable interest of researchers this area. Major findings are reported below.

Firstly, it has been observed that with the decline in effectiveness of traditional marketing, marketers are heading towards contemporary strategies like viral marketing. Viral marketing is an innovative tactic that encourages people to pass message. Secondly, viral marketing has become a key component of promotional strategy, as it has many advantages over traditional promotional strategies. Following table describes the difference between traditional marketing campaigns and viral marketing campaigns. 
Table 2: Difference between Traditional Marketing and Viral Marketing

\begin{tabular}{|c|c|c|}
\hline Basis of comparison & Traditional Marketing & Viral Marketing \\
\hline Spread & Narrow. & Wider. \\
\hline Control & $\begin{array}{l}\text { Full control over the message and its } \\
\text { direction. }\end{array}$ & Lack of control \\
\hline Reach & $\begin{array}{l}\text { Marketer has to reach to each customer } \\
\text { separately. }\end{array}$ & $\begin{array}{l}\text { Marketer once communicate } \\
\text { a message to only few people } \\
\text { then these few people pass } \\
\text { on the message further. }\end{array}$ \\
\hline Cost effectiveness & Low & High \\
\hline Exposure & Limited & $\begin{array}{l}\text { Wide exposure across } \\
\text { countries. }\end{array}$ \\
\hline $\begin{array}{l}\text { Measurement of } \\
\text { effectiveness }\end{array}$ & Relatively easier. & Complex. \\
\hline Flow of information & One way (marketer to customer). & Multi-directional. \\
\hline Feedback time & Delayed and offline. & Real time. \\
\hline Channels & Television, newspaper etc. & $\begin{array}{l}\text { E-mail, blogs and social } \\
\text { networks. }\end{array}$ \\
\hline
\end{tabular}

It is clear from the above table that viral marketing has many advantages over traditional forms of marketing. However there are also some limitations in viral marketing strategies and that is why one cannot be sure about the effectiveness and convenience of conventional marketing. There is a need of combination of contemporary and conventional marketing strategies.

Further it is observed that there is lack of control in viral marketing campaigns and there is an uncertainty about success of message. So before making a message viral the marketer has to keep some determinants in mind. There are four major factors that directly determines the power of a message of getting viral as indicated in the figure below.

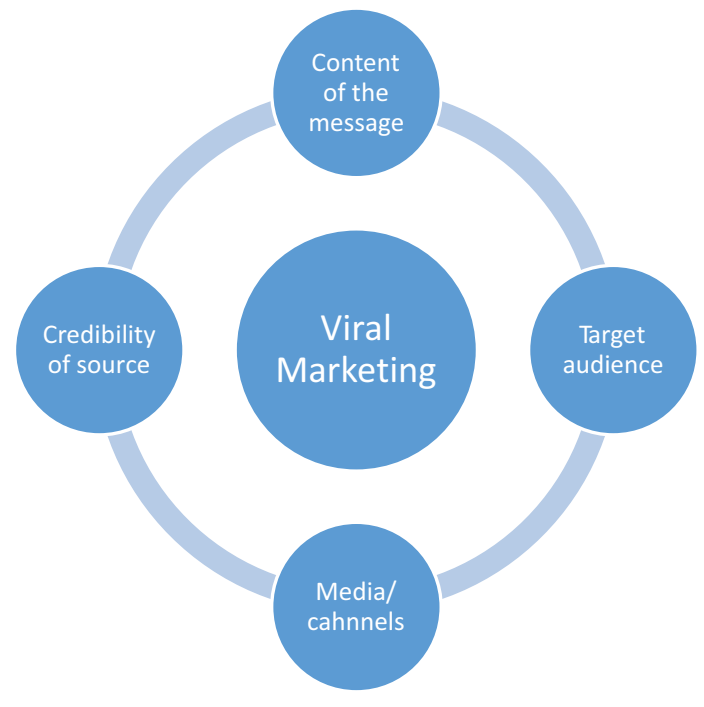

Figure 1: Factors determining the effectiveness of a viral marketing campaign 
- The message: The effectiveness of a viral marketing campaign somewhat depends upon the content of the message. A marketer has to consider some points before designing a message. It must have adequate information in it. Presentation of the message also plays an important role in success of the campaign. Emotional appeal should be used in the advertising campaign of an old and well established product whereas rational appeal should be used where the product is relatively new. Effectiveness also depends upon the timing of delivery of the message. If the message is delivered during a particular time period i.e during festive season then its effectiveness usually increases. It is also observed that the greater the frequency of delivery, the greater will be the return. It is necessary that the message should be able to grab the attention of the audience. The message must not be too manipulative because it can irritate its audience and result into negative attitude. Sometimes a message that has some monetary reward attached to it gets viral easily. As people are compensated for every share.

- Target Audience: It has been observed that existing customers are more likely to pass on the message. If the target audience is active and highly involved then it would be easy for the marketer to get its message viral. Effectiveness of a campaign also depends upon the consumer level of direct and indirect experience with the product.

- Media: The effectiveness of viral marketing campaign also depends on the media used for running the campaign. Before deciding the medium to be used marketer has to keep some points like reach, easy access on web, rapid flow of information and flow across nations in mind.

- Credibility of Sources: The effectiveness of an advertising campaign also depends upon the source the message is coming from. It can be passed on by any source but it has been observed that if it is coming from an influencer then it would have a greater impact. Further it is observed that the customers are likely to believe and pass on the ads if they are coming from an existing and familiar company and also people generally believe on experienced consumer.

\section{CONCLUSION}

In this paper we conclude that there is a huge difference between conventional and contemporary strategies of promotion. Viral marketing is increasingly become in promotional strategy. The reason for which could be cost effectiveness and wide reach but lack of control and difficulty in measuring the effectiveness there is a need to combine both approaches. These strategies are not mutually exclusive but work together. Viral marketing is at an early stage of expansion and most of current literature focuses on increasing trend of eWOM. Despite of large number of literature, factors that directly influence the success/ effectiveness of a viral marketing campaign have been neglected. The present study tries to fill this gap and explains factors that determine the effectiveness of viral marketing campaign. However this study has several limitations that open avenues for further research. The first limitation of the study is that it follows an exploratory research method. The determinants of viral marketing needs further exploration. These kind continuously evolving strategies need continuous review over a period of time. Further research can also be done by using other research methods like cross sectional.

\section{REFERENCES}

1) Steyer, R. Garcia-Bardidia, P. Quester, Online discussion groups as social networks: An empirical investigation of word-of-mouth on the internet, Journal of Interactive Advertising1 (2004)51-59.

2) Arnaud DeBruyn and Gary Lilien. A multi-stage model of word of mouth through electronic referrals. 2004.

3) Baidu Encyclopedia,Wordofmouthmarketing (2006) 
4) http://baike.baidu.com/view/932115

5) Blattberg, Robert C. and John Deighton (1991), "Interactive Marketing: Exploiting the Age of Addressability," Sloan Management Review, 33 (1), 5-14.

6) D. Bowman and D. Narayandas(2001). Managing customerinitiated contacts with manufacturers: The impact on share of category requirements and word-of-mouth behavior. Journal of Marketing Research Vol. 38 No. 3 pp. $281-297$

7) Danilo, Cruz. and Chris Fill, "Evaluating Viral Marketing: Isolating the Key Criteria", Marketing Intelligence \& Planning, Vol. 26 (7), 2008 pp. 743-758.

8) Datta, P., Chowdhury, D., \& Chakraborty, B. (2005). Viral marketing: New form of word- ofmouth through internet [Electronic version]. The Business Review, Cambridge, 3 (2), 69-75.

9) Dobele, A., A. Lindgreen, M. Beverland, J. Vanhamme, and R. van Wijk (2007).,"Why pass on viral messages? Because they connect emotionally. Business Horizons", 50 (4) pp. 291304

10) Fattah, H.M. (2000), “Viral marketing is nothing new", Technology Marketing Intelligence, Vol. 20 No. 10, pp. 1-3

11) Goldenberg, Jacob Barak Libai, and Eitan Muller (2001), "Talk of the Network: A Complex Systems Look at the Underlying Process of Word-of-Mouth," Marketing Letters, 12 (3), 211223.

12) Helm, S. (2000), "Viral marketing: establishing customer relationship by 'word-of-mouse'", Electronic Markets, Vol. 10 No. 3, pp. 158-61.

13) J. J. Brown and P. H. Reingen (1987). Social ties and word-of-mouth referral behavior. The Journal of Consumer Research, Vol.14 No. 3:350-362

14) J.Chevalier,D.Mayzlin, (2006) The effect of word of mouth on sales: Online book reviews, Journal of Marketing Research 26 345-354.

15) J.E. Phelps, R. Lewis, L. Mobilio, D. Perry (2004), Viral marketing or electronic word-of-mouth advertising: Examining consumer responses and motivations to pass along email, Journal of Advertising Research 333-348.

16) Jurvetson, Steve, Draper, Tim, 1997. Viral Marketing retrieved on 21 September 2017

17) http://www.dfj.com/HYPERLINK "http:// www.dfj.com/files/viralmarketing.html"fiHYP ERLINK "http: // www.dfj.com / files/ viralmarketing.html"les/viralmarketing.html.

18) Kaikati, Andrew M. and Jack G. Kaikati (2004), "Stealth Marketing: How to Reach Consumers Surreptitiously," California Management Review, 46 (4), 6-22.

19) Kempe, D., Kleinberg, J., Tardos, E., 2005. Influential nodes in a diffusion model for social networks. Automata, Languages and Programming)

20) Kiss C, Bichler M, (2004) "Identification of influencers - measuring influence in customer networks",in Decision Support Systems, Vol. 46 No 1 pp. 233-253.

21) Knight, C.M. (1999), "Viral marketing - defy traditional methods for hyper growth", Broadwatch Magazine, Vol. 13 No. 11, pp. 50-3.

22) M. S. Granovetter. The strength of weak ties. American Journal of Sociology, 78:1360-1380, 1973.

23) Ratchford, Brian T. (2015), "Some Directions for Research in Interactive HYPERLINK "http:// refhub.elsevier.com / S1094-9968(15) 00048-1 / rf0520" Marketing, Hyperlink "http:// refhub. elsevier.com / S10949968(15)00048-1/rf0520"" Journal of Interactive Marketing, 29, 0, -vHyperlink "http://refhub. elsevier.com / S1094-9968 (15) 000481/rf0520"Hyperlink "http://refhub.elsevier. com/S1094-9968(15)00048-1/rf0520"vii. Ries, Eric (2011), The Lean Startup: How Constant Innovation Creates Radically Successful Businesses. London: Portfolio-Penguin.

24) Thomas, Greg M., Jr. (2004), “Building the Buzz in the Hive Mind," Journal of Consumer Behavior, 4 (1), 64-72.

25) Welker, C.B. (2002), "The paradigm of viral communications", Information Services \& Use, Vol. 22, pp. 3-8. 
26) Wilson, R.F. (2000), "The six simple principles of viral marketing", Web Marketing Today, Vol. 70, pp. 1-3.

\section{Exhibits}

Table 2: correlation of term Viral with other words

\begin{tabular}{|l|c|}
\hline Terms & Correlation \\
\hline campaign & 0.81 \\
\hline impact & 0.81 \\
\hline campaigns & 0.8 \\
\hline rates & 0.8 \\
\hline frequently & 0.79 \\
\hline used & 0.79 \\
\hline advertising & 0.78 \\
\hline ad week & 0.78 \\
\hline increasingly & 0.78 \\
\hline marketing & 0.78 \\
\hline subservient & 0.78 \\
\hline academic & 0.77 \\
\hline happy & 0.77 \\
\hline mates & 0.77 \\
\hline men & 0.77 \\
\hline short & 0.77 \\
\hline strengths & 0.77 \\
\hline
\end{tabular}

Table 3: Word Counts

\begin{tabular}{|l|l|}
\hline marketing & 5492 \\
\hline viral & 3056 \\
\hline social & 1804 \\
\hline research & 1432 \\
\hline network & 1395 \\
\hline product & 1353 \\
\hline model & 1339 \\
\hline information & 1211 \\
\hline influence & 1199 \\
\hline number & 1192 \\
\hline campaign & 1136 \\
\hline
\end{tabular}




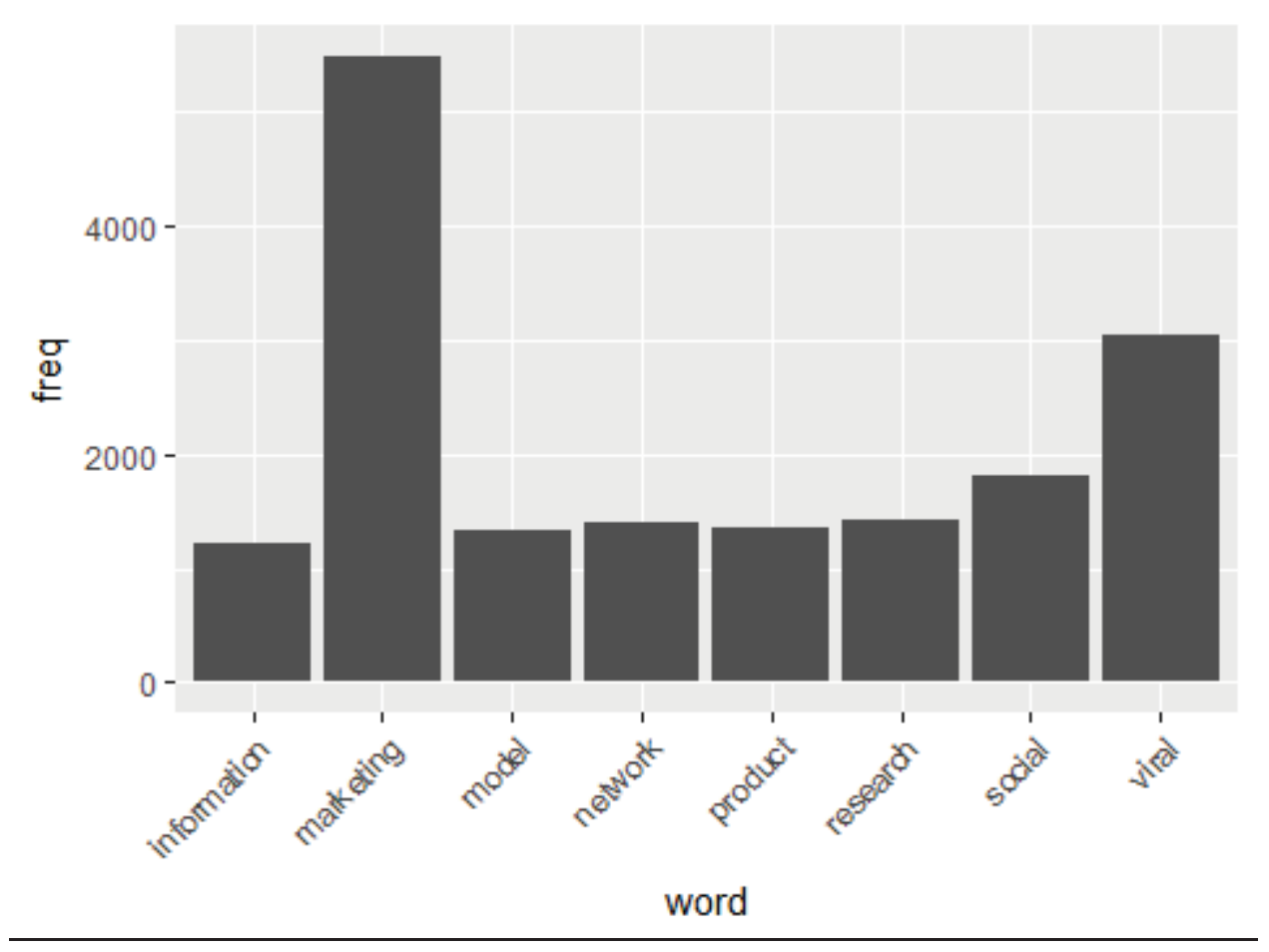

Figure 2: Word Frequency plot with frequency 